S1-05

小腸オリゴペプチドトランスポーターの組織・ 細胞内分布と薬物輸送特性

金沢大·薬 ○玉井 郁巳、林 喜代美、崔 吉道、辻 彰、 金沢大·医東田 陽博、

徳島大·医＼cjkstart白神 俊幸、宮本 賢一、武田 英二

\title{
TISSUE- AND INTRA-CELLULAR DISTRIBUTION OF INTESTINAL OLIGOPEPTIDE TRANSPORTER AND ITS FUNCTIONAL CHARACTERIZATION
}

Ikumi TAMAI ${ }^{1}$, Kiyomi HAYASHI ${ }^{1}$, Yoshimichi SAI ${ }^{1}$, Akira TSUJI ${ }^{1}$, Haruhiro HIGASHIDA ${ }^{2}$, Toshiyuki SHIRAGA ${ }^{3}$, Ken-ichi MIYAMOTO $^{3}$ and Eiji TAKEDA ${ }^{3}$

${ }^{1}$ Faculty of Pharmaceutical Sciences and ${ }^{2}$ School of Medicine, Kanazawa University, Kanazawa 920, Japan and ${ }^{3}$ School of Medicine, Tokushima University, Tokushima 770, Japan.

【目的】 $\beta$-ラクタム抗生物質には多くの誘導体が存在するが、側鎖 $\alpha$ 位にアミノ基を有するアミノ- $\beta$-ラクラム抗生物質をはじめとして、脂 溶性が低いにもかかわらず消化管吸収性の良好な誘導体がある。このこ とから小腸上皮細胞において何らかの特殊輸送系、特にオリゴペプチド 輸送系の関与が考えられ、多くの研究がなされてきた。近年、プロトン 勾配を駆動力とするオリゴペプチド輸送担体PepTファミリーが米国 Leibach等のグループや我々を含め、いくつかのグループによって、ウサ ギ、ヒトおよびラット小腸から相次いでクローニングされた(1-5)。これ らの輸送担体は、Northern解析等により消化管以外の臓器にも発現して いることが明らかにされているが (1-5)、ファミリーによって、また種に よっても分布が異なり、消化管からの $\beta$-ラクタム抗生物質吸収への寄与 を含め、その他の輸送への関与については、いまだ完全に明らかになっ ていない。本研究では、消化管からの $\beta$-ラクタム抗生物質吸収に対する オリゴペプチド輸送担体PepT1の寄与を明らかにする目的で、ラット小 
腸から単離されたクローン、ラットPepT1の輸送特性を外来性遺伝子発 現系を用いて解析した。また、本輸送系が経細胞輸送のいずれの過程に 関与するかを明らかにする目的で、小腸上皮細胞における細胞内局在性 および組織分布について免疫化学的手法等を用いた検討を加えた。

【方法】 ウサギPepT-1 (1) の塩基配列をプローブにそのラットホモロ グを小腸CDNAライブラリーから単離し、得られたクローンの輸送活性 を、アフリカツメガエル卵母細胞を用いた外来遺伝子発現系により評価 した。ジペプチド、グリシルザルコシンの取り込みは放射性標識体を用 いることにより、また薬物の定量はHPLCで行った。抗PepT1ポリクロー ナル抗体は以下のように作成した。PepT1のアミノ酸配列を基に抗原ペ プチドを設計、合成した。合成ペプチドを $m$-maleimidobenzoyl- $N$ hydroxysuccinimide-esterによりキャリア蛋白（keyhole limpet hemocyanin） と架橋し、50-100 $\mu$ gペプチド当量にアジュバントを加えエマルジョン化 し約 2 週間おきにウサギに免疫した。その後、抗血清を得、適宜アフィニ ティカラム等により精製した。

【結果および考察】 ラットPepT1 の $\left[{ }^{14} \mathrm{C}\right]$ glycylsarcosineに対する輸送活 性をアフリカツメガエル卵母細胞を用いて検討したところ、顕著な $\mathrm{pH}$ 依 存的輸送能を示した。その輸送は、種々のジーおよびトリペプチドによっ て阻害されたが、構成アミノ酸、挹よびテトラ-またはペンタペプチドに よる阻害は見られなかった（図1）。従って、本輸送担体がジ-およびト リペプチドを特異的に認識するオリゴペプチドトランスポーターである ことが示された。このラットPepT1の $\beta$-ラクタム抗生物質輸送能を、ジ カルボン酸型抒よび両性イオン型誘導体としてセフチブテンおよびセフ アドロキシルをそれぞれ選び検討したところ、いずれの基質に対しても $\mathrm{pH}$ 依存的輸送活性が見られた。さらに、セフチブテンについてはトラン ス体とシス体で輸送活性に違いがあり、PepT1は立体選択性も有してい 


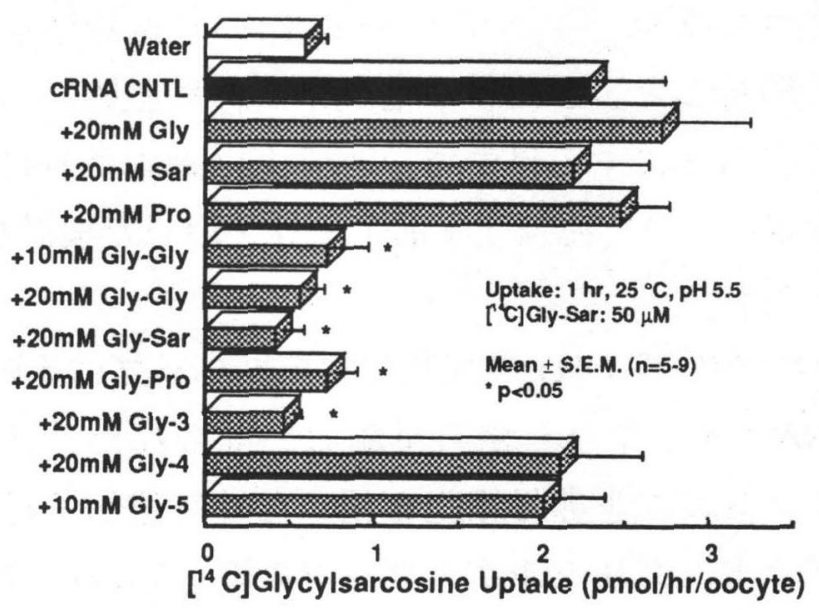

図1 ラットPepT1による $\left[{ }^{14} \mathrm{C}\right]$ グリシルザルコシン取込みに対する阻害効果。
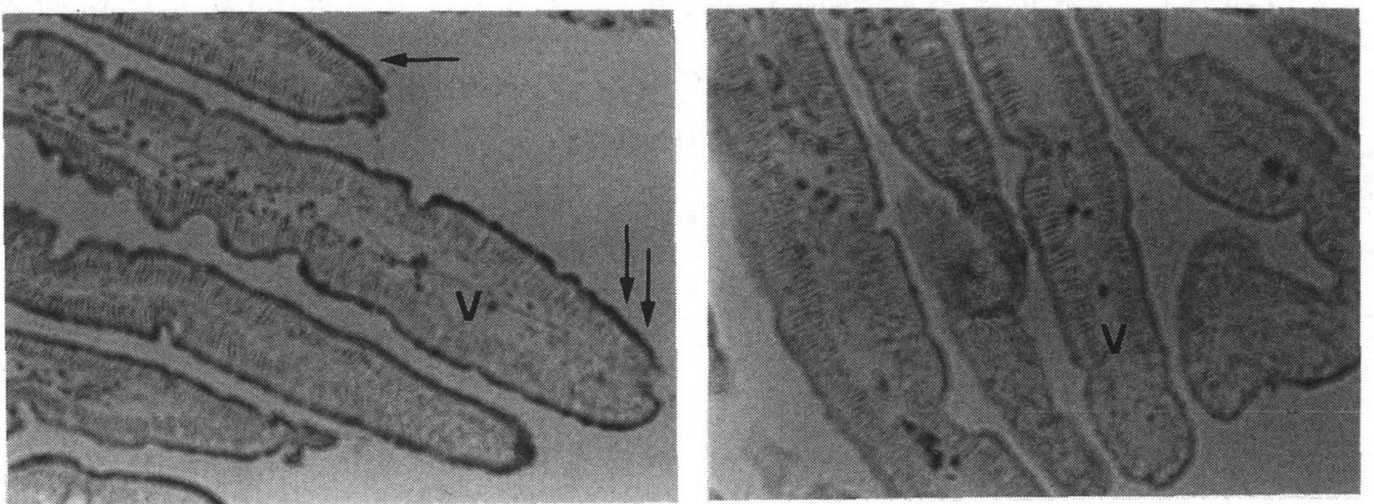

図2 抗PepT1抗体による空腸PepT1の免疫染色。左:抗PepT1抗血清, 右:正常血清, V:絨毛。

ることが示された。以上の結果より、単離したラットPepT1がオリゴペ プチドおよび $\beta$-ラクタム抗生物質を輸送することが明らかとなった。 $\beta$-ラクタム抗生物質の小腸での輸送におけるPepT1の寄与について、 小腸上皮全mRNAを卵母細胞に微注入し、PepT1翻訳開始領域に対するア ンチセンスオリゴヌクレオチドの効果を検討したところ、セフチブテン の輸送活性がほほ対照群と同程度まで減少した。同様の結果はウサギ小 腸mRNAによる輸送活性についても得られ、 $\beta$ - ラクタム抗生物質の輸送 にPepT1が非常に大きな役割を担っているものと考えられた。

PepT1の組織分布をNorthern解析により検討したところ、ウサギおよび 
ヒトと同様、小腸および腎に多く発現していたが、ウサギおよびヒトと は異なり肝での発現は少なかった。小腸上皮細胞におけるPepT1の細胞 内局在性および組織分布性について、PepT1に対するポリクローナル抗 体を作成し、小腸上皮細胞の細胞分画および各組織切片固定標本との反 応性を検討した。その結果、主に小腸上皮細胞刷子縁膜に存在すること が示された（図2）。

以上、本輸送担体が、 $\beta$-ラクタム抗生物質の消化管吸収に大きな寄与 を持つこと、更に消化管管腔から上皮細胞への吸収過程において機能し ている可能性が示唆された。

【ABSTRACT】 Function and tissue- and intra-cellular distributions of rat intestinal oligopeptide transporter, rat PepT1, cloned as a homologue of rabbit PepT1, were studied. Functional characteristics of a rat PepT1 were evaluated by measuring transport activities expressed in Xenopus laevis oocytes injected with complementary RNA for PepT1 synthesized by in vitro transcription. Rat PepT1 exhibited a pH-dependent transport of $\left[{ }^{14} \mathrm{C}\right]$ glycylsarcosine and the transport was specifically inhibited by di- and tripeptides but not by their constitutive amino acids or tetra- and pentapeptides. Rat PepT1 also transported ß-lactam antibiotics with $\mathrm{pH}$-dependent and stereoselective manners. Furthermore, transport activities expressed in oocytes injected with intestinal total mRNA were abolished by the hybridization of the mRNA with an antisense oligonucleotide against PepT1. Polyclonal antibody against PepT1 was prepared and used for immunohistochemical analysis of PepT1. PepT1 was strongly detected in intestinal epithelium, especially in the brush-border side. Accordingly, PepT1 was shown to function in the uptakes of oligopeptides and peptide-like drugs from intestinal lumen to epithelial cells.

\section{【REFERENCES】}

1) Fei, Y.-J. et al., Nature, 368, 563-566 (1994).

2) Liang, R. et al., J. Biol. Chem., 270, 6456-6463 (1995).

3) Liu, W. et al., Biochim. Biophys. Acta, 1235, 461-466 (1995).

4) 奥田真弘等、日本薬学会第115年会要旨集4、pp. 103 (1995).

5) Miyamoto, K. et al., Biochim. Biophys. Acta, submitted. 